\title{
Neglected Cases of Breast Abscess
}

\author{
Authors \\ Dr Amit Kumar Gupta, Dr Khwaja Nasim Ahmad (Asso-Prof), Dr A.J. Malik (Prof), \\ Dr Sukesh Kumar, Dr Saumya Sinha \\ General Surgery Katihar Medical College Katihar Bihar, India
}

\section{Breast Abscess}

Sixty Eight cases of severe breast infection are presented. The first patient was admitted with a gangrenous left breast and was in septic shock. She died soon after admission. The another case had bilateral breast abscesses and was toxic. She also died after treatment with antibiotics and multiple debridments. The Sixty Six patient with bilateral severe breast infection had right mastectomy. She made a rapid improvement. It is proposed that mastectomy may be a reasonable option for management of advanced or neglected breast infection or necrotising fasciitis of the breast.

\section{Introduction}

Advanced sepsis forms a major component in the pattern of diseases seen in the Department of Surgery, Katihar Medical College, Katihar. Infections such as extensive streptococcal cellulitis, necrotising fasciitis and pyomyositis are common'. Moreover neglected advanced sepsis appears to be on the increase, usually because of inadequate primary treatment and delayed presentation to hospital due to financial and transport constraints. Of late the same pattern of neglected sepsis has been noted in breast infections. This paper had 100 such cases in which three cases are described.

\section{Case 1}

A 36-yeal- old female patient was admitted at Katihar Medical College, Katihar a week after she had breast abscess and getting local treatment. At the time of admission the patient had a gangrenous left breast and was in septic shock. On investigation Attempts were made to resuscitate her with intravenous fluids, parenteral antibiotics and immediate excision of all the necrotic tissue. She did not recover and died some hours later.

\section{Case 2}

A 26-year old female was admitted with a twoweeks history of bilateral multiple breast abscesses. The patient had been breast-feeding for three week. This patient was also toxic on admission; she was treated with drainage of abscesses parenteral antibiotics, intravenous fluids and multiple debridements. 


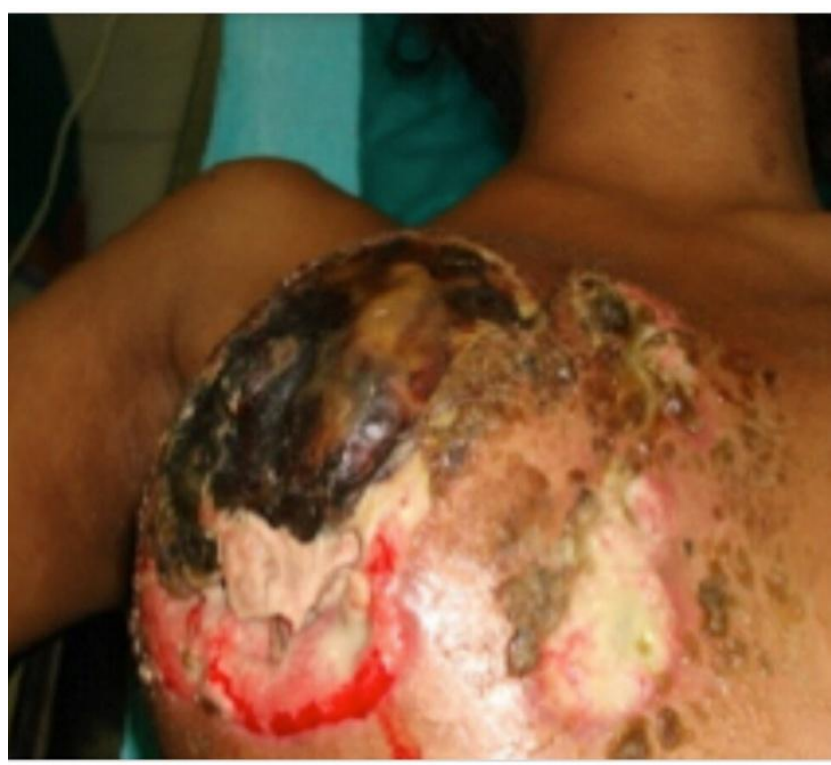

\section{Case 3}

A 31-years old female was referred to us from the Obstetrics and Gynaecology Department. The junior doctor writing the consultation had stated: "Kindly come and see a patient with bilateral breasts reaching up to her waist. The breasts are both infected and are bogging the patient down. She cannot stand or sit." The patient had just delivered a baby that morning.

On examination she was toxic, had systemic sepsis clinically and she was seriously ill. The patient was already on parenteral antibiotics and I.V. fluids. She was in constant pain and requested that both her breasts be removed.

In view of her request and the unusual nature of the operation the consent of the husband for such unorthodox surgery was necessary. The consent was finally obtained and she underwent partial mastectomy of the more severely infected right breast. She received a unit of blood because of her severe anaemia. More units were not available. Following mastectomy the patient's condition rapidly improved and the operation wound healed with a transient infection. Following complete healing of all wounds the patient decided not to proceed with the mastectomy of the grossly enlarged remaining breast.

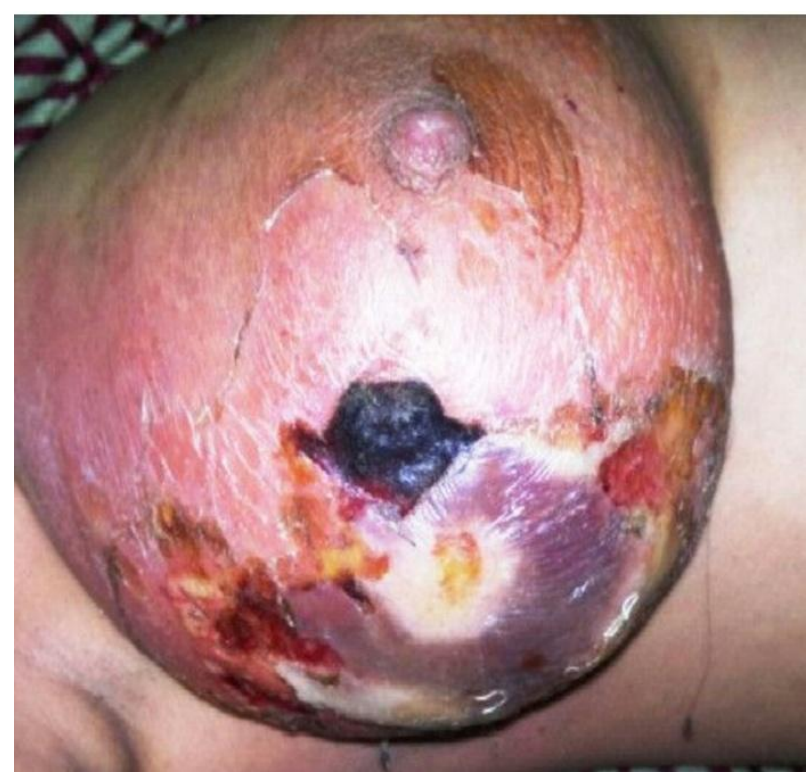

\section{Case 4}

A 28 year old female reported to the opd of katihar medical college with chief complaint of swelling in the right breast. she was on medication 3 weeks localy for swelling and pain in right breast. which is on examination tender and firm of size $6 \mathrm{cmx} 5 \mathrm{~cm}$. FNAC REPORT ANTIBIOMA. excision of antibioma was DONE .

\section{Discussion}

Excision of infected breast tissue is now recommended as the treatment of choice for periareolar non-lactating abscesses ${ }^{2,3}$ such abscesses can be caused by peri-ductal mastitis and mammary duct ectasia. The treatment recommended is to excise all the sinus tracts and terminal ducts under the areola ${ }^{2,3}$. Lactation however will not be possible from the breast that has undergone this operation ${ }^{3}$. Interestingly in the 1950 's in the Gabon, the French illustrated a patient with giant breasts and described the condition as elephantiasis; one form of which was caused by streptococcal infection resulting in permanent elephantiasis ${ }^{4}$. Our patients showed evidence of long standing extensive sepsis affecting all of the breast tissue. With such a presentation, local excision would certainly have been an inadequate form of treatment and with the development of systematic inflammatory response (SIR), which all three patients showed clinically, a 
more radical step such as mastectomy was a logical course for consideration. It is likely that a judicious early mastectomy in the taro patients who died of uncontrolled sepsis could have been life saving as demonstrated by the patient who underwent mastectomy. Unorthodox as the mastectomy may seem it could be looked upon as an extension of ductal excision ${ }^{2,3}$ and under some circumstances be justified.

\section{References}

1. Stephen W. Bickler, Heinz Rode. Priorities for pediatric Surgery in Africa. Africa Health. 2000; 22:5.

2. Finck C, Meguid Numann PJ, Oler A. Periareolar Breast Abscess: Re-defining the diseases and Treatment. Medscape women's Health. 1997;2(12):2 State University of New York Health Science Centre at Syracuse, N.Y.

3. Fetter G.K. Current Management of breast sepsis. In: Veler M, Saadia R, Keeton J Eds, Common surgical Emergencies. Abstract. University of Witwatersrand, Johannesburg, Sout Africa, 1997;July 6-7: pages 158-162.

4. Nouveau Larousse Medical Librairie Larousse Paris 1952;370. 